\title{
Assessment of Forest Degradation and Food Insecurity of Farming households in Ibadan-Ibarapa Agricultural Zone of Oyo State, Nigeria
}

\author{
Sanusi Wasiu Adekunle*, Fanifosi Gbenga Emmanuel \\ Department of Agricultural Economics, Ladoke Akintola University of Technology, Ogbomoso, Oyo State, Nigeria \\ *Corresponding Author \\ Sanusi Wasiu Adekunle
}

\section{Article History}

Received: 13.06.2020

Accepted: 20.06 .2020

Published: 30.07 .2020

\begin{abstract}
Achieving sustainable food security for halve of the world population by 2025 is currently under threat because the multifaceted contribution of forest to household food security are shortened by the degradation of forests. This study however, examine the economic implication of forest degradation and food insecurity of farming households in Ibadan-Ibarapa Agricultural Development zone of Oyo State, Nigeria. The contribution of forest degradation to households' food insecurity and its policy implication on food requirement. Both descriptive and inferential statistics were used to analyze the information obtained from one hundred and eighteen valid questionnaires. The forest-based farmers were sampled through a multistage sampling procedure; villages around the forest reserves in the zone were considered in the selection process and contact farmer. The result revealed that $59.2 \%$ of the respondents were food insecure while $40.8 \%$ were food secure. The food shortfall index was 0.68 and surplus of 2.51 . Fuel wood, agricultural practices, charcoal production, logging for timber, wild fire, industrial expansion, games hunting, excessive grazing, inconsistence in government policies (forest-based) and changes in weather with its events are the main causes of forest degradation in the study area. Non-wood forest products such as vegetables, fruits, games, condiment are source of the peoples' food where they obtain their daily food requirement. And that, farming experience $(\mathrm{P} \leq 0.01)$, household size $(\mathrm{P} \leq 0.1)$, excessive forest grazing $(\mathrm{P} \leq 0.05)$, income from games $(\mathrm{P} \leq 0.1)$ and logging $(\mathrm{P} \leq 0.1)$ significantly influence food insecurity in the area. Therefore, the study suggests policies that will limit the rate of exploiting the forests to aid forest degradation improvement.
\end{abstract}

Keywords: Degradation, Food, Forest, Household, Improvement.

\section{INTRODUCTION}

Development of forest began to take recognition in Nigeria in 1889 with emphasis on forest reservation and regulated timber exploitation [13]. Report have it that, the increasing demand of forest products became significant in 1980 's, due to rise in population pressure and economic growth, the demand for timber became high. As a matter of this, the country began to experience unchecked forest exploitation, thus resulting in degradation of the forest resources in the country.

Degradation as a terminology simply mean a loss of original ecological integrity that is, loss of species diversity, forest structure and its productivity. The Food and Agriculture Organization of the United Nations [7] has defined forest degradation as changes within a forest that affect the structure and function of the stand or site and thereby lower its capacity to supply products or services. Frequent occurrence of fire outbreak, unauthorized logging, fuel wood collection, agronomic and cultivation practices (like shifting cultivation), game hunting and the prevalence of climate change effect (drought) form the major cause of forest degradation today.

The rate of depletion of forest in Nigeria is fast becoming noticeable. FORMECU [11] observed that between 1980 and 1990, the rate of deforestation stood at 3.5\% and by 2018, it has increase to about $11 \%$. This comes according to the claim of Regional Centre of Expertise on Education (RCE) for sustainable Development [18]. Enabor, E. C [5] argued that, land clearance for cropping by subsistence farmers in shifting cultivation account for about $80 \%$ of the

Copyright @ 2020: This is an open-access article distributed under the terms of the Creative Commons Attribution license which permits unrestricted use, distribution, and reproduction in any medium for non commercial use (NonCommercial, or CC-BY-NC) provided the original author and source are credited. 
deforestation in Nigeria. The report of Federal Department of Forest [10] supported the claims by observing that inadequacies in forest management plan, under-utilization of resources, primitive silvicultural operations and high rate of unauthorized logging contributed immensely to the depletion of forest in Nigeria. The mismanagement of the forestland in the course of logging activities and agricultural production resulted in the formulation of forest reservation policy. But the policy that emerged was not based on adequate knowledge of ecology, biology and silviculture of the natural forest ecosystem as argued by [16].

Forests are source of food and medicine, though it does not only provide food items, but also essential in the provision of fuel for cooking, helps in livelihood diversification and improve agricultural production through soil protection and water provision. It supports diversification of livelihoods of farm families through increased income earnings that aid household food security. Forest-based food helps against seasonal food shortage and offer security in the period of climatic stress events such as flood or drought. During the off season, when conventional agricultural crops are unavailable, households depend heavily on forest products which could be either games or wild fruits. In many instances, forests and trees are used to maintain domestic nutritional standards when other food products cannot be purchased or produced in large quantities in the community [17].

Forest degradation has not only affected the climatic environment, but it has serious influence on the food insecurity. Households who depend on the forest products as their source of food, nutrition and livelihood are at the suffering end of threats that forests currently faced. The loss of forest or degradation aggravate the problem of food insecurity. According to [19], the problems could appear directly through shortage of fruits and other forest food products (plants and animals) or indirectly modifying ecological factors relevant for crop and livestock and thereby affecting the availability of food. In eliminating hunger and nutritionally balanced diets, food from forest can in no measure contribute an essential part for farming households, this is one of the reasons why many depend on forests [3].

\section{Methodology}

The study was carried out in Ibadan-Ibarapa Agricultural development zone (ADP). About 3 forest reserve was situated in the region. Adopting a multi-stage sampling, the first stage of the sampling involves purposive selection of two forest reserve in the area. The second stage involve random selection of three villages each within the province of the forest reserves; lastly, proportionate sampling was used to select one hundred and sixteen farming households from all the villages selected. With a well-structured questionnaire that provided full information on the objective of the study, an interview was granted to the household heads. The study used descriptive statistics, and logit regression model to analyse show the implication of forest degradation on food security status of the farm family around the selected forest reserves in the study area.

\section{Model Specification}

This study adopts food insecurity index used by [1] to establish the household food security of the respondents. In doing this, two different steps were involved that is, recommendation and aggregation. The Recommendation stage involved defining the minimum level of nutrition necessary to maintain healthy living - (the food security line) for the population understudy below which households are classified as food insecure. Nutrient content from self-produced foods and the purchased food items by household constitute the measure of the calorie availability for the farming households.

With a daily recommendation level of $2500 \mathrm{kcal}$ per capita as proposed by [9] the households were categorized into food secure and insecure. Households who are able to cross the threshold were classified as food secure while those that were below the threshold line were food insecure. Aggregation, on the other hand, derived food security statistics for the households. Daily per capital calorie consumption was estimated by dividing the estimated daily calorie supply to the household by the household size. Availability was estimated using food nutrient composition.

Food security index $\Phi=\frac{\text { Household's daily per capita calorie availability (A) }}{\text { Household's daily per capita calorie requirement }}$

For a household to be food secured, $\Phi$ must be greater than or equal to one $(\Phi \geq 1)$, while $\Phi$ less than one ( $\Phi$ $<1)$ suggest that the household is food insecure.

The Headcount ratio $(\mathrm{H})$ is a measure of food security status and it is defined as

$$
H=\frac{Q}{N}
$$

Where,

$\mathrm{Q}=$ the number of the food-insecure

$\mathrm{N}=$ sample population 
Food Insecurity Gap $(\Omega)$ : this is a measure of the depth of food insecurity and it is expressed as:

$$
\Omega_{\mathrm{i}}=\frac{\mathrm{ACRi}-A C \mathrm{Ci}}{\mathrm{ACRi}} \text {. }
$$

Where,

$\Omega_{\mathrm{i}}=$ Food insecurity gap of $\mathrm{i}^{\text {th }}$ food insecure household

$\mathrm{ACC}_{\mathrm{i}}=$ Aggregate calorie consumption by $\mathrm{i}^{\mathrm{th}}$ food insecure household

$\mathrm{ACR}_{\mathrm{i}}=$ Aggregate calorie requirement for $\mathrm{i}^{\text {th }}$ food insecure household

The total food insecurity gap or shortfall index is expressed as:

$\mathrm{TFIG}=\sum \frac{(A C R \mathrm{i}-A C C \mathrm{i})}{A C R \mathrm{i}}$

Square food insecure Gap: this indicate the severity of food insecurity among the food insecure household and it is given as:

$$
\mathrm{SFIG}=\sum{\frac{(\Omega \mathrm{i})^{2}}{Q}}^{2}
$$

\section{Logit Regression model}

Logit regression model was used to analyse the contribution of forest degradation on food insecurity of the forest-based farmers. The explicit model was stated as;

$$
\mathrm{L}_{\mathrm{i}}=\alpha+\beta_{1} \mathrm{X}_{1}+\beta_{2} \mathrm{X}_{2}+\ldots \ldots \ldots \beta_{\mathrm{k}} \mathrm{X}_{\mathrm{ik}}+\mu_{\mathrm{i}}
$$

Where

$\mathrm{L}_{\mathrm{i}}=$ Food insecurity status (food insecure $=1$, otherwise $=0$ ). The covariates $\left(\mathrm{X}_{\mathrm{i}} \mathrm{s}\right)$ are farmer's specific socioeconomic characteristics and forest-based variables.

$\mathrm{X}_{1}=$ Age

$\mathrm{X}_{2}=$ House hold size (number)

$\mathrm{X}_{3}=$ Years of formal education

$\mathrm{X}_{4}=$ Years of experience in farming

$\mathrm{X}_{5}=$ Farm size $($ ha)

$\mathrm{X}_{6}=$ Distance to forest

$\mathrm{X}_{7}=$ Excessive forest grazing

$\mathrm{X}_{8}=$ Income from games

$\mathrm{X}_{9}=$ other income

$\mathrm{X}_{10}=$ Logging

\section{RESULTS AND DiSCUSSION}

\section{Socioeconomic characteristics of the forest-based farmers in the study area}

The result in Table-1 shows that majority (51.3\%) of the respondents are within the age group of 41-60 years, $34.6 \%$ of the respondents are within the age group of 20-40 years and the average age was of the farmers stood at 47.8 . This shows that majority of the respondents are still in their active and productive age; the result support the argument of $[12,6]$. Most $(85 \%)$ of the respondents are male while $15 \%$ of the respondents are female. The variation may be due to the fact that male was more involve in agricultural production than female. Female are more into processing and marketing of agricultural produce as their male counterpart are in production due to drudgery nature of most of the agricultural activities. The result further reveals that most $(86.7 \%)$ of the respondents were married, $3.1 \%$ were still single and about $9.2 \%$ being divorced. The household size has the highest percentage $(65.3 \%)$ with respondents who has between 6 and 10 family members, 31.5\% have household sizes from 1-5 and 3.2\% have 10 and above members. The mean of household sizes was 6.2; implying moderate size to a farm family where members of the family are used for farm labour. More than $36 \%$ of the respondents had between 11-20 years of farming experience, $20.2 \%$ of the respondents had between 1-10 years, $19.4 \%$ had 31-40 years of farming experience and the average years of experience stood at 23.5. This implies that majority of the respondents are experienced forest-based farmers and they are expected to have cognitive knowledge and experience on the state of the forest more than a decade [4]. 
Table-1: Distribution of Respondents' Socioeconomic Characteristics

\begin{tabular}{|c|c|c|}
\hline Socioeconomic variables & Frequency & Percentage \\
\hline \multicolumn{3}{|l|}{ Age (Years) } \\
\hline $20-40$ & 44 & 37.3 \\
\hline $41-60$ & 61 & 51.7 \\
\hline Greater than 60 & 13 & 11.0 \\
\hline \multicolumn{3}{|l|}{ Mean $=47.8$} \\
\hline Total & 118 & 100.0 \\
\hline \multicolumn{3}{|l|}{ Gender } \\
\hline Male & 93 & 78.8 \\
\hline Female & 25 & 21.2 \\
\hline Total & 118 & 100.0 \\
\hline \multicolumn{3}{|l|}{ Marital Status } \\
\hline Single & 3 & 2.5 \\
\hline Married & 96 & 81.4 \\
\hline Widowed & 10 & 8.5 \\
\hline $\begin{array}{l}\text { Divorced } \\
\text { Total }\end{array}$ & $\begin{array}{l}9 \\
118\end{array}$ & $\begin{array}{l}7.6 \\
100.0\end{array}$ \\
\hline \multicolumn{3}{|l|}{ Household size } \\
\hline $1-5$ & 41 & 34.8 \\
\hline $6-10$ & 74 & 62.7 \\
\hline Above 10 & 3 & 2.5 \\
\hline \multicolumn{3}{|l|}{ Mean $=6.2$} \\
\hline Total & 118 & 100.0 \\
\hline \multicolumn{3}{|l|}{ Education } \\
\hline No formal education & 27 & 17.3 \\
\hline Primary & 57 & 48.3 \\
\hline Secondary & 29 & 24.6 \\
\hline Tertiary & 3 & 2.5 \\
\hline $\begin{array}{l}\text { Adult } \\
\text { Total }\end{array}$ & $\begin{array}{l}1 \\
118\end{array}$ & $\begin{array}{l}0.8 \\
100.0\end{array}$ \\
\hline \multicolumn{3}{|c|}{ Farming Experience (Years) } \\
\hline $1-10$ & 30 & 25.4 \\
\hline $11-20$ & 41 & 34.7 \\
\hline $21-30$ & 21 & 17.8 \\
\hline $31-40$ & 19 & 16.2 \\
\hline Above 40 & 7 & 5.9 \\
\hline \multicolumn{3}{|l|}{ Mean $=23.5$} \\
\hline Total & 118 & 100.0 \\
\hline \multicolumn{3}{|l|}{ Farm size (Acres) } \\
\hline $1-5$ & 56 & 47.5 \\
\hline $6-10$ & 42 & 35.6 \\
\hline $11-15$ & 16 & 13.6 \\
\hline $16-20$ & 3 & 2.5 \\
\hline Above 20 & 1 & 0.8 \\
\hline \multicolumn{3}{|l|}{ Mean $=7.1$} \\
\hline Total & 118 & 100.0 \\
\hline
\end{tabular}

Source: Field Survey 2018

\section{Causes of Forest Degradation}

The perceived means of forest degradation were identified by the respondents; this include fuel wood, agricultural practices, charcoal, logging for timber, wild fire, industrial expansion, hunting games, grazing, inconsistence in government policies (forest-based) and changes in weather and its events. Food and Agriculture Organisation [8] forest degradation are mainly promoted by either human-induced activities (Agriculture and settlements) or weather events such as flooding, earthquake or volcanic eruption. 
Table-2: Perceived cause of Forest Degradation

\begin{tabular}{|l|l|l|}
\hline Causes & Frequency & Percentage \\
\hline Fuel wood & 71 & 21.1 \\
\hline Agriculture & 75 & 22.3 \\
\hline Charcoal & 58 & 17.2 \\
\hline Logging for timber & 44 & 13.1 \\
\hline Wild fire & 29 & 8.6 \\
\hline Industrial expansion & 1 & 0.3 \\
\hline Hunting of games & 18 & 5.3 \\
\hline Grazing & 12 & 3.6 \\
\hline Change in weather and it events & 14 & 4.2 \\
\hline Change in government policies & 15 & 4.5 \\
\hline Total & 337 & 100.0 \\
\hline
\end{tabular}

Source: Field Survey 2018

Multiple responses

\section{Income generating activities}

\section{Wood Product Derived from the forest}

Table-3 revealed that $73.7 \%$ obtain fuel wood from forest, $17.2 \%$ claimed to source poles from the forest, while about $9 \%$ of the respondents obtain sawn wood. Forest has a great potential as timber wood materials (timber) form the forest is one of the exporting materials which contribute to the economic growth of the nation before the discovery of oil [13].

Table-3: Distribution of Respondents wood product derived

\begin{tabular}{|l|l|l|}
\hline Wood product & Frequency & Percentage \\
\hline Fuel wood & 180 & 73.7 \\
\hline Poles & 42 & 17.2 \\
\hline Sawn wood & 22 & 9.1 \\
\hline Total & 244 & 100.0 \\
\hline
\end{tabular}

Source: Field Survey 2018

Multiple Responses

\section{Non- Wood Product obtain from the Forest}

Table- 4 shows the non- wood product obtained in the forest by the respondents. About $21 \%$ of respondents claim to obtain medicinal plants, $20.1 \%$ claim that game meat were sourced from the forest, $17.7 \%$ claimed forest to be the major source of leaves. Forest is also a major source to obtain condiment, fruits, vegetables, nectar and rubber as identify by the respondents. The result support the assertion of $[2,14]$ who claimed that forest support provision of good and healthy nutrition with high micronutrients for people.

Table-4: Distribution of Respondents by Non-Wood Product Derived

\begin{tabular}{|l|l|l|}
\hline Non-Wood Product & Frequency & Percentage \\
\hline Game-meat & 79 & 20.1 \\
\hline Medicine plant & 81 & 20.6 \\
\hline Oil & 9 & 2.3 \\
\hline Leaves & 70 & 17.7 \\
\hline Rubber & 7 & 1.7 \\
\hline Nectar & 2 & 0.5 \\
\hline Condiment & 43 & 10.9 \\
\hline Fruits & 61 & 15.5 \\
\hline Vegetables & 42 & 10.7 \\
\hline Total & 394 & 100.0 \\
\hline
\end{tabular}

Source: Field Survey 2018

Multiple Responses

\section{Food Security Status}

The mean food insecurity index was 3.0 for food secure household and 0.7 for the food insecure households. The result shows 49 households to be food secure while 71 were food insecure with their percentage as $40.8 \%$ and $59.2 \%$ respectively. About $30000 \mathrm{kcal}$ was reported as the average households' daily calorie intake for the food secure household and $15273.4 \mathrm{kcal}$ for the food insecure households. The food surplus was 2.51 which indicated that household 
who are food secure exceed the daily calorie intake by $251 \%$. The food shortfall was 0.68 which also indicated that the food insecurity household were short of daily calories by $68 \%$. This shows that food insecurity was high in the study area. Despite the closeness of the study area to forests reserve, this high incidence of food insecurity suggests that there might be an excessive degradation of the forests in which the rich diversity of resources have been exploited.

Table-5: Food security status of the respondents

\begin{tabular}{|l|l|l|}
\hline Food security indices & Food Secure & Food Insecure \\
\hline Number of households & 49 & 71 \\
\hline Percentage of households & 40.8 & 59.2 \\
\hline Household size & 5.3 & 7.4 \\
\hline Mean food insecurity index & 3.01 & 0.66 \\
\hline Mean households daily calorie intake(kcal) & 29942.8 & 15273.4 \\
\hline Mean household per capita daily calorie intake (kcal) & 5649.6 & 2063.9 \\
\hline Food surplus/insecurity gap & 2.51 & 0.68 \\
\hline Headcount ratio & 0.41 & 0.59 \\
\hline
\end{tabular}

Source: Field Survey, 2018

\section{Contribution of forest degradation on food insecurity status of the forest-based farmers}

Both demographic and forest-based variables were fitted into the logit regression model to estimate the contribution of forest degradation to household food insecurity. The result as presented on Table- 6 shows the coefficient of household size, Excessive Forest grazing and logging to be positively related to food insecurity of the forest-based farmers in the study area while farming experience, years spent in school and income from game hunting shows negative relationship with food insecurity. The result indicated that an increase in household size, Excessive Forest grazing and logging in the forest, the likelihood of increased food insecurity in the study area is pertinent. Also, the indication of both farming experience, years spent in school and income from game hunting being negative to food insecurity was that an increase in both variables will increase the chance of exiting food insecurity. Farmers gather more experience of dealing with their production with time and due to the changes in weather events which occur with time, experience of the farmer will play roles in food security of the household. Likewise, education plays major role in exiting food insecurity, this is in consonance with the findings of [15].

Table-6: Estimate of food security of forest-based farmers using logit regression model

\begin{tabular}{|l|l|l|l|l|}
\hline Variables & Coefficient & Standard error & Z-ratio & $\mathbf{P}>\mathbf{Z}$ \\
\hline Constant & -4.759 & 2.829 & -1.682 & $0.093^{*}$ \\
\hline Age & 0.036 & 0.049 & 0.719 & 0.472 \\
\hline Household size & 0.224 & 0.080 & 2.80 & $0.005^{* * *}$ \\
\hline Years in school & -0.042 & 0.021 & -2.049 & $0.025^{* *}$ \\
\hline Farming experience & -4.15 & 0.215 & -1.928 & $0.063^{*}$ \\
\hline Farm size & 1.933 & 1.312 & 1.473 & 0.141 \\
\hline Distance to forest & 0.017 & 0.118 & 0.140 & 0.888 \\
\hline Excessive Forest grazing & 0.042 & 0.021 & 2.049 & $0.024^{* *}$ \\
\hline Income from games & -0.181 & 0.010 & -1.728 & $0.085^{*}$ \\
\hline Other income & 0.006 & 0.043 & 0.131 & 0.073 \\
\hline Logging & 0.364 & 0.198 & 1.840 & $0.065^{*}$ \\
\hline
\end{tabular}

Source: Fields survey 2018

Note: *** significant $1 \%$; ** significant at $5 \%$ and $*$ significant $10 \%$

\section{CONCLUSION AND RECOMMENDATION(S)}

The findings from this work reveals that most of the forest-based farmers were in the productive age with an average household member of 6 which constitute large part of family labour on farm. With cognitive experience in farming, most of the farmers were literate. Both wood and non-wood products are obtained from the forest which constitute large part of their income generating activities. The result further showed that the farmers rely mainly on nonwood forest products for their daily food requirement. This help many of them in sourcing micronutrients that are beneficial to their health and growth. Household size, excessive forest grazing, logging, farming experience, years spent in school and income from game hunting were identify as the major factor influencing food insecurity in the study area. However, this study suggests a proactive policy that will reduce the excessive and unauthorized plundering of the forest reserve. 


\section{REFERENCES}

1. Ahmed, U. I., Ying, L., Bashir, M. K., Abid, M., \& Zulfiqar, F. (2017). Status and determinants of small farming households' food security and role of market access in enhancing food security in rural Pakistan. Plos One, 12(10): e0185466.

2. Arnold, M., Powell, B., Shanley, P., \& Sunderland, T. C. H. (2011). Forests, biodiversity and food. security Int For Rev, 13(3):259-264, Commonwealth Forestry Association

3. Bhaskar, V., Wildburger, C., \& Stephanie, M. (eds). (2015). Forests, trees and landscapes for food security and nutrition. A global assessment report. IUFRO World Series, 33. Vienna, Austria.

4. Dlamini, S. G., Ogunniyi, L. T., Villane, F. M., \& Fanifosi, G. E. (2019). Impact of agricultural input subsidy on productivity of small-scale maize farmers in the Hhohho Region of Eswatini. International Journal of Development and Sustainability. 8(12):785-794

5. Enabor, E. C., \& Popoola, L. (1994). Nigeria forest revenue system and proposal. Unpublished FORMECU, Abuja.

6. Fanifosi, G. E., \& Amao, J. O. (2016). Socioeconomic analysis of nexus between food insecurity and poverty status of farming households in Osun State, Nigeria. International Journal of Advance Agricultural Research IJAAR 1(1), 30-36.

7. FAO. (2002). Proceedings: Expert meeting on harmonizing forest- related definitions for use by Various Stakeholders. Rome. 23-25 January 2002.

8. FAO, (Food and Agriculture Organization of the United Nations). (2006). Reducing emissions from deforestation in developing countries. Food and Agriculture Organization of the United Nations Rome.

9. FAO, (Food and Agriculture Organization). (2010). "The state of food insecurity in the World, Food and Agriculture Organization of the United Nations". Rome.

10. FDF. (1998). Country report; Nigeria session of African Forestry and wildlife commission. Dakar, Senegal. 8-17 April, 1998. Federal Department of Forestry Abuja Nigeria.

11. FORMECU. (1993). Forest revenue system development in Nigeria: Proceedings of seminar on Forest revenue system development in Nigeria held in Benin City. Edo State. 10-11, Nov 1993.

12. Ganiyu, M. O., Fanifosi, G. E., \& Ariyo, C. A. (2016). Analysis of poverty level among timber millers in Osogbo Agricultural Development Zone of Osun state, Nigeria. Nigerian Journal of Rural Extension and Development. 5057.

13. Geomatic Nigeria limited. (1997). Forestry development in Nigeria. Paper presented Forest Resource study workshop held at FDF. Abuja.14 November 1997.

14. Mohamed-Katerere, J., \& Smith, M. (2013). The role of ecosystems in food security. Unasylva, 64(2):14-22.

15. Ogunniyi, L. T., Fanifosi, G. E., \& Komolafe, O. D. (2017). The contribution of urban agriculture to household food insecurity in Ibadan metropolis, Oyo State Nigeria. Scientia Agriculturae, 17(2)42-47

16. Osemeobo, G. J. (1998). Community participation in biological diversity conservation;- A case study of community herbal centre, Otun-Ekiti, south west, Nigeria. Federel Environment protection Agency (FEPA), Abuja.

17. Tidwell, T. L. (2016). Nexus between food, energy, water, and forest ecosystems in the USA. Journal Environ Stud Sci, 6:214-224.

18. Vanguard. (2018). Nigeria loses its forests at the rate of $11.1 \%$ annually. www.vanguardngr.com/2018/06/nigerialoses-forests-rate-of-11-1-annually-centre/

19. Van Noordwijk, M., Bizard, V., Wangpakapattanawong, P., Tata, H. L., Villamor, G. B., \& Leimona, B. (2014). Tree cover transitions and food security in Southeast Asia. Global Food Security, 3(3-4): 200-208. 